Article

\title{
Back to Nature and Moral-Spiritual Rediscovery: Lessons from Lao Tzu and St. Augustine on Human Conduct in Modern Society
}

Jove Jim S. Aguas

\begin{abstract}
Modern life is convenient, efficient and comfortablethanks to the advancement in technology in the modern society. But it is also problematic, complicated and sometimes meaningless and it breeds complacency, greed and discord. So the question that confronts us today is: how do we live or conduct ourselves is modern society with all its trappings and yet preserve our sense of dignity and simplicity? How do we live a life that is comfortable and meaningful, efficient and contented, convenient and natural? To get some insights we turn to the past and look for some lessons from two important thinkers and masters from the Western tradition-St. Augustine and the Eastern tradition-Lao Tzu. They are two prominent thinkers who came from different cultures, different religious orientations and times. The society and time they came from may be different from ours but they can still offer us some lessons how to live a simple and meaningful life in a modern society. Lao Tzu tells us that we need to go back to nature, follow the way of the Tao and be guided by the wu-wei. St. Augustine advices us that while we are physical and mortal creatures, we need to rediscover our moral and spiritual nature and live according to our divine image. Indeed the wisdom of the past both from the East and West can definitely guide us and give us valuable lessons.
\end{abstract}

Keywords: St. Augustine, Taoism, wu-wei, human conduct

\section{Introduction}

$\mathrm{W}$

hile modern society with its advancement in technology, economics and business has made human life more comfortable, efficient, exciting and convenient, it has also bred discord, greed,

(c) 2015 Jove Jim S. Aguas

http://www.kritike.org/journal/issue 16/aguas june2015.pdf

ISSN 1908-7330

$(c c)$ BY-NC-ND 
complacency, and arrogance. Life seems so easy yet it is also problematic; life seems purposely driven yet meaningless; life seems so alive yet empty, so convenient yet so complicated. We have advanced in knowledge yet we lack critical consciousness. We have become intelligent as to harness the resources of nature, yet we have become insensitive and unwise as to how to preserve nature. Modern living and advances in technology is like a double-edged sword, they could be so good yet so dangerous; they could be so beneficial yet so harmful. We cannot reverse the course of time and go back to the past when everything was so simple, so natural yet so fulfilling and meaningful, at least compared to how things are now. And we cannot ignore the convenience, the excitement, the efficiency, and comfort of modern living. We cannot oppose this modern advancement and go against technology, because whether we admit it or not, life has been easy and convenient for us because of what modern technology can do for us. So the question that confronts us today is: how do we live or conduct ourselves is modern society with all its trappings and yet preserve our sense of dignity and simplicity? How do we live a life that is comfortable and meaningful, efficient and contented, convenient and natural?

Lao Tzu and St. Augustine are two prominent thinkers from different cultures, different religious orientations, and times. They may be remote from our present time and their type of society may be different from our present society and yet, they can still offer us some lessons how to live a simple and meaningful life in a modern society. In this paper, I will reflect on some lessons from Lao Tzu and St. Augustine on how to conduct of lives in a modern society. The wisdom of the past both from the East and West can definitely guide us today. At the onset, we can say that from Lao Tzu we get the admonition that we need to go back to nature, follow the way of the Tao and be guided by the $w u$-wei. From St. Augustine, we get the advice that while we are physical and mortal creatures, we need to rediscover our moral and spiritual nature and live according to our divine image. The world is not our final destination, we are in a spiritual journey, and our final destination is a world beyond this world. The two masters are telling us that we need to follow nature because we are one with it and rediscover the spiritual and moral nature within us.

\section{The Tao and the Invariable Laws}

Literally, tao means "way" or "path." The doctrines of Taoism are contained in the book "Tao Te Ching" which is attributed to Lao Tzu. ${ }^{1}$

${ }^{1}$ Lao Tzu, according to the Records of History by Sima Qian, is believed to have been an elder contemporary of Confucius and the author of the Tao-Te Ching. See Macmillan Encyclopedia of Philosophy, $2^{\text {nd }}$ edition, vol. 5 (New York: Thompson Gale, 2006), 192.

(c) 2015 Jove Jim S. Aguas

http://www.kritike.org/journal/issue 16/aguas june2015.pdf

ISSN 1908-7330

(cc) BY-NC-ND 
Instead of presenting a philosophic system, Lao Tzu expresses a sense of the ultimate, underlying great principle, rule, or cause of "the way of all things." His vision of reality is holistic; it encompasses the totality of the cosmos. According to Lao Tzu, viewed holistically, the universe expresses harmony, purpose, order, and calm power, but when we attempt to separate things just to understand the parts without understanding the whole lead to error, suffering, and unhappiness.

Tao has several meanings: 1) the primordial principle from which all things emanate and which underlies all that is, 2) that which operates in all that is and which provides the natural way of being and acting, 3) that which provides norm of morality. ${ }^{2}$

Lao Tzu observes that although things are ever changeable and changing, the laws that govern them are not themselves changeable. These laws are called "invariables" from the Chinese word "ch'ang" which could also be translated as eternal or abiding. Hence for Lao Tzu, the word "ch'ang" is used to show what is always so and it can be considered as a rule. To be enlightened is to know the invariable law of nature. Among the laws that govern the change in nature or things, the most fundamental is that "when a thing reaches one extreme, it reverts from it." In the Tao Te Ching, Lao Tzu writes: "Reversion is the action of the Tao." 3 He also says: "Functioning everywhere means far-reaching, far-reaching means returning to the original point." 4 The idea is that if anything develops certain extreme qualities, those qualities invariably revert to become their opposites. Too much wealth will revert to poverty, too much power or strength will revert to weakness; conversely, too much ignorance will revert to knowledge. To resist this process or rule would be to go against the law of nature. The opposites are not only mutually causal; they are of merely relative value in comparison with one another. So, for instance, beauty has meaning only in relation to an opposite meaning of ugliness and the same is true with good and evil, difficult and easy and other opposites. Hence, the good and bad both exist in an everlasting exchange. Rain for example is good in time of drought and bad in time of flood.

These seem to be paradoxical theories, but they are not paradoxical, if one understands the fundamental law of nature. To the ordinary people who have no idea of this law, they seem paradoxical indeed. Lao Tzu says, "When the highest type of men hear the Tao, they diligently practice it, when the average type of men hear Tao, they have believe it, when the

\footnotetext{
${ }^{2}$ D. Liu, The Tao and Chinese Culture (London: Routledge and Kegan Paul, 1981), 4.

3 Tao Te Ching, trans. by Ariane Rump (Hawaii: Society for Asian Comparative Philosophy, 1979), chapter 40.

${ }^{4}$ Ibid., Chapter 25.

(c) 2015 Jove Jim S. Aguas

http://www.kritike.org/journal/issue 16/aguas june2015.pdf

ISSN 1908-7330
}

(c) BY-NC-ND 
lowest type of men hear Tao, they laugh heartily at it." 5 To know the "invariable" is to be liberal, that is, to be without prejudice, to be generous towards things. The man who comprehends the "invariable" and relies upon it for his action does not follow his own partial opinion and therefore without prejudice. Because the Tao is "all pervading and unfailing"; 6 the man who comprehends and relies on the "invariable" may likewise become all pervading and unfailing and thus he will not fail throughout his lifetime. This is called "practicing enlightenment." The enlightened man associates the Tao with spontaneity and creativity; he frees himself from selfishness and desire, and appreciates simplicity.

\section{The Wu-Wei and Te}

From the general theory that "reversing" is the movement of the Tao," the well-known Taoist theory of wu-wei is deduced. According to this theory everything comes from the ultimate "wu" or "nothing" which is the "unnamed" or the "invisible." The Tao consequently acts by "non-acting." $W u$-wei's literal translation means "having no activity" or "non-action," but it does not actually mean complete absence of activity, or doing nothing. It could mean lesser activity or doing less or acting without artificiality or arbitrariness. ${ }^{7}$ The goal of $w u$-wei is to achieve a state of perfect equilibrium, or alignment with Tao, revealing the soft and invisible power within all things and, as a result, obtain an irresistible form of "soft and invisible" power.

Activities are like many other things. If one has too much of them, they become harmful rather than good. The purpose of doing something is to have something done or accomplished, but if there is overdoing, if there is excessive activity, then, the result may be worse than not having the thing done at all. A well-known Chinese story describes how two men were once competing in drawing a snake: the one who would finish first would win. One of them having finished his drawing he saw that the other man was still far behind, so decided to improve it by adding feet to his snake. Thereupon the other man said, "You have lost the competition, for a snake has no feet." Over-doing defeats its own purpose. Over-eagerness could lead to not accomplishing anything at all. To follow the wu-wei therefore is to act naturally and spontaneously. Artificiality and arbitrariness are the opposites of naturalness and spontaneity. Man should restrict his activities to what is necessary and what is natural. Necessary means necessary to the

\footnotetext{
${ }^{5}$ Ibid., Chapter 41.

${ }^{6}$ Ibid., Chapter 25.

${ }^{7}$ Fung Yu-Lan, A Short History of Chinese Philosophy, Ed. by Derk Bodde (New York: Macmillan Publishing Co. Inc., 1966), 100.
}

(c) 2015 Jove Jim S. Aguas http://www.kritike.org/journal/issue 16/aguas june2015.pdf ISSN 1908-7330 
achievement of a certain purpose, and not over-doing. Natural means following one's Te with no arbitrary effort. In doing this, one must take simplicity as the guiding principle of life. In ancient Taoist texts, wu wei is associated with water through its yielding nature. Water may appear to be soft and weak, but it can move earth and carve stone. The universe works harmoniously according to its own ways. When someone exerts his will against the world, he disrupts that harmony. The way of the Tao is the natural way; in nature, everything goes well with it and in it.

In the process of coming to be, each individual thing obtains something from the universal Tao, and this something is called "Te." The nature of a thing is it "Te" its power or virtue. The Te is the power of the Tao revealed in the world of phenomena, together with the 'virtue' that this power brings in anyone or anything that follows the 'way.' Virtue is genuineness or being true to one's own nature that is, avoiding artificiality and pretense. Man loses his original virtue or Te because he has too many desires and too much knowledge, and when he tries to satisfy his many desires, he obtains opposite results. In his desire to accomplish his many objectives, he resorts to artificiality; he breaks the law of nature, and moves away from the way of the Tao. Lao Tzu paradoxically also emphasizes that people should have little knowledge because knowledge itself is an object of desire. Knowledge enables man to know more about the objects of desire and serves as a means to gain these objects. But with increasing knowledge, man is no longer in a position to know how to be content and where to stop; the result is excess or the extreme. The wise man is very conscious of the work of the Te in everything, giving them the power to develop according to their own nature. He does not interfere, he just let things be. He follows the wu-wei and to follow the wu-wei is not to be passive but to conform to the law of Nature which is the law of the Tao working through its powers. Lao Tzu writes: "The all-embracing quality of the great virtue (te) follows alone from the Tao." 8 The man who is enlightened in the Tao and practicing enlightenment in his life embodies the Taoist ethical ideal; he is the sage. The sage is different from the common man. The sage knows the Invariables, the laws of nature and conducts his activities in accordance with them. He knows the general rule that if he wants to achieve anything, he must start from the opposite, and if he wants to preserve anything he admits in its something of its opposite, it one wants to be strong, one must start by feeling weak. ${ }^{9}$

In the sage, the paradoxical qualities of the Tao: being through nonbeing, action through non-action and strength through softness all are

\footnotetext{
8 Ibid., Chapter 21.

${ }^{9} \mathrm{Yu}-\mathrm{Lan}, 99$.
}

(c) 2015 Jove Jim S. Aguas

http://www.kritike.org/journal/issue 16/aguas june2015.pdf

ISSN 1908-7330

(c) BY-NC-ND 
present. He understands that to yield is to be preserved whole, to be bent is to become straight, to be empty is to be full, to be worn out is to be renewed, to have little is to possess, to be plenty is to be perplexed. Therefore, the sage embraces the One, and becomes model of the world. He does not show himself, yet he is luminous. He does not justify himself, yet he becomes prominent. He does not boast himself, yet gains merit. He does not brag, yet he can endure long. It is precisely because he does not compete that the world cannot compete with him. ${ }^{10}$ The sage understands that strength is gained through softness. Lao Tzu further adds:

What is most perfect seems to be incomplete; but its utility is unimpaired. What is most full seems to be empty; but its usefulness is inexhaustible. What is most straight seems to be crooked. The greatest still seems to be clumsy. The greatest eloquence seems to be stutter. Hasty movement overcomes cold. But tranquility overcomes heat. ${ }^{11}$

This is the way in which a sage or a prudent man can live safely in the society and the world in general and achieve his aims. This is Lao Tzu's answer and solution to the original problem of the Taoist, which was, how to preserve life and avoid harm and danger in the human world. This is also the lesson we can learn as to how to conduct and live in the modern world. The man who lives prudently must be meek, humble, and easily content. To be meek is the way to preserve ones strength and to be strong. Humility is the direct opposite of arrogance, so that if arrogance is a sign that a man's advancement has reached its extreme limit, humility is a contrary sign that limit is far from reached. And to be content safeguards one from going too far and therefore from reaching the extreme. Therefore Lao Tzu writes, "To know to be content is to avoid humiliation; to know where to stop is to avoid injury." 12 The sage therefore discards the excessive, the extravagant, and the extreme. The sage learns from the reversal motion of the Tao when to stop. Aware that when things develop extreme qualities they invariably revert to opposites, the sage is cautious that he does not over exert himself. He discards what is excessive and extravagant. Lao Tzu states:

To hold and fill to overflowing is not as good as to stop in time. Sharpen a sword-edge to its very sharpest, and

\footnotetext{
${ }^{10}$ See Ibid., Chapter 22.

11 Ibid., Chapter 45.

${ }^{12}$ Ibid., Chapter 44.
} 
(the edge) will not last long. When gold and jade fill your hall, you will not be able to keep them. To be proud with honor and wealth, is to cause one's own downfall. Withdraw as soon as your work is done. Such is heaven's way. ${ }^{13}$

The most important point to realize is that, in order to live in any specified manner, one must begin by living in a manner exactly the opposite. If we want to be strong we have to be weak because by being weak one is strong, by staying at the background, one is in the foreground. The man who knows the Invariables knows that the movement of the Tao is reversal. Therefore, he avoids going to the extremes. From Lao Tzu, we learn therefore that human conduct must characterized by spontaneity, humility, simplicity, non-interference and contentment. ${ }^{14}$ Spontaneity best captures in a positive value what Lao Tzu meant by non-action. Non-action does not mean never acting at all; it means opposing only purposeful action that is why he said that a sage's behavior should take nature as its model. Thus to be a sage one must negate the attitude that one is an agent who must act to impose his will on everything and everyone around him. Humility is the best attitude of a sage. It keeps man from reaching the extreme. By being humble, one never reaches the limit. When things are done and one doing them humbly relinquishes all claims to merit, is far from the limit and he has mastered the natural way. Non-interference is also an attitude of the sage. Water symbolizes the behavior of the sage because it does not compete, but rather takes the path of least resistance. Since interfering in the affairs of others or the operations of nature is the worse product of willful activity, Lao Tzu advises us that we must back away from all meddlesome behavior. Such behavior is not only harmful but also pointless.

\section{The Desires of Man}

St. Augustine enunciates that religious faith and philosophical understanding are complementary rather than opposed and that one must "believe in order to understand and understand in order to believe." $\mathrm{He}$ combines the Neo-Platonic notion of the One and the Christian concept of a personal God who created the world and predestined its course. Our ultimate destination is God and St. Augustine insists that although we achieve a certain degree of happiness in the physical things for they are

\footnotetext{
${ }^{13}$ Ibid., Chapter 9.

${ }^{14}$ Yu-Lan, A History of Chinese Philosophy, 183.
} 
reflections of God's goodness, we cannot conceive of true happiness without the permanence that only God can assure. It is impossible to attain true happiness here in this world for it can only provide us with things that are temporary and fleeting. God is the supreme object and natural goal of our activity, the ultimate resting place of our love.

Since our desire for happiness is the love of God, no created good can capture our heart except by presenting a reflection of the absolute Good and portraying the countenance of God. Through its creative act, our will receive a direct participation in the subsisting goodness and it is for this reason that the movement of love can find repose only in God: "our heart is restless until it rest in Thee."15

According to St. Augustine, all men desire happiness and peace and everything is directed towards this goal. But the material man desires only a material happiness and a temporal peace; the spiritual man on the other hand the man who loves God, seeks a spiritual happiness and an eternal peace. These two loves produce two types of human beings and two types of states. St. Augustine enunciates that based on these two loves two cities are built, the earthly which built up by the love of self to contempt of God, and the heavenly, which is built up by the love of God to the contempt of self. ${ }^{16}$ St. Augustine further writes:

In the city of the world both the rulers themselves and the people they dominate are dominated by the lust for domination; whereas in the City of God all citizens serve one another in charity, whether they serve by the responsibilities of office or by the duties of obedience. ${ }^{17}$

For St. Augustine, the two cities based on the two loves of man cannot be separated. The good and the bad citizens are mixed. The real purpose of the citizens should be to attain harmonious living with each other and peace among them. St. Augustine wants to emphasize that the earthly dwelling is temporal and is but a shadow of a higher dwelling. He is firmly convinced that the earthly (society) must follow the ideal heavenly state, that it must live in concord and peace of righteous men in union among themselves under God and in God's presence. Through the process of time and by God's grace, the increase in religious conviction will diminish man's desire for the earthly or social life. However, the heavenly

${ }^{15}$ St. Augustine, The Confessions, trans. by John K. Ryan (New York: Image Books Doubleday, 1960) Book 1, chapter 1, 1, 43.

16 St. Augustine, The City of God, trans. by Gerald Walsh, Demetrius Zema, Grace Monahan \& Daniel Honan (New York: Image Books, 1958),Bk. 14, Chapter 28, 321.

${ }^{17} \mathrm{Ibid}$.

(c) 2015 Jove Jim S. Aguas

http://www.kritike.org/journal/issue 16/aguas june2015.pdf

ISSN 1908-7330 
city uses also the earthly peace in the course of its earthly pilgrimage. It cherishes and desires, as far as it may without compromising its faith and devotion, the orderly coherence of men's wills concerning the things which pertains of the mortal nature of man. Earthly peace is important in the attainment of heavenly peace. Hence, it does not mean that the two loves, the two desires, the two cities are irreconcilable. The temporal society or the human society is a preparation towards the ultimate goals, towards the discovery of faith, hope, and love of God through other people.

\section{The Human Person as a Wanderer and his Ultimate End}

The human person or man, for St. Augustine, is an intermediate creature between brutes and angels - a rational animal with a body and soul, guided and ordered by the loving Providence of a personal God.18 The two characteristics faculties of the human person are the intellect and the will. The end of the intellect is the possession of the immutable Truth while the end of the will is the union with the immutable Good. The Truth and the Good are united into one in the Being of God. So for St. Augustine, the union and the possession of God is the ultimate destiny of man and Divine Providence guides man in his quest to attain his destiny.

However, man is a being of flesh and bone and exists and lives in the space-time continuum. He is also a man of this world and true to his material nature he also loves or desires the objects in this world. The goodness of creation is also the goodness of God. ${ }^{19}$ But, for St. Augustine, although man is in the world, because he has a body, he is not of the world because he has a spiritual nature and his soul cannot find fulfillment in the world. The secular affairs of man are mere manifestations of his fundamental reality - the state of his soul. And it is the spiritual in man that gives integrity and meaning to his personal life and human destiny. The passing events in this world are mere pre-figurations and symbols to prepare man for his eternal destiny. For St. Augustine, it is the divine in man that directs him towards his ultimate end and destiny which is heavenly happiness. The divine image is the compass of human life. Thus, when it was shattered by sin, man became lost and disoriented. He became a stranger to his own nature, a stranger to his destiny, a stranger to himself. St. Augustine compares man's spiritual disorientation to a group of wanderers who wanted to return to their homeland. He writes:

${ }^{18}$ St. Augustine, The City of God, Bk. 5, Chapter 11, 111.

${ }^{19}$ St. Augustine, City of God, book 11, chapter 22.

(c) 2015 Jove Jim S. Aguas

http://www.kritike.org/journal/issue 16/aguas june2015.pdf

ISSN 1908-7330

(c) BY-NC-ND 
Suppose, then we were wanderers in a strange country and could not live happily away from our fatherland, and wishing to put an end to our misery, determined to return home. We find however, that we must make use of some mode of conveyance, either by land or water, in order to reach the fatherland where our enjoyment is to commence. But the beauty of the country to which we pass, and the very pleasure of the motion, charm our hearts, and turning these things which we ought to use into objects of enjoyment, we become unwilling to hasten to the end of our journey and becoming engrossed in fictitious delight, our thoughts are diverted from that home whose delights would make us truly happy. ${ }^{20}$

Like wanderers, man seeks to return to his fatherland or homeland which is the Kingdom of God. Man's life is a spiritual journey, but is often distracted by the things of this world and he is continually entrapped in its temporal and material grandeur. One of the obstacles that can befall man in his spiritual journey is to love the world over God. He might get so absorbed in the passing grandeur of the world to the point of loving the creatures more than the Creator, not knowing that the material and temporal grandeur of the world is but an imperfect reflection of God. Man's excessive love for the world is a love that degrades man's own nature and true destiny.

God who is the end the destination of man's spiritual journey is the source of true happiness. "The striving after God is, therefore, the desire of beatitude, the attainment of God is beatitude itself."21 Thus, God as the highest beatitude or happiness of man serves as the fundamental criterion for moral valuation. Man, however, cannot ascend to God without being detached from creatures or worldly things. Virtue entails an intellectual and moral purification through which our intellect and will are progressively detached from every sensible object. Man cannot ascend to God if he is attached to worldly things, he must abandon all attachments to worldly happiness. The virtues are thus important for they are those that temper the worldly desires of man. Through the virtues, man is able to detach himself from the worldly pleasures. The goal of this detachment and purification in this life is the future life, where man can have a loving contemplation of God.

${ }^{20}$ St. Augustine, On Christian Doctrine, trans. by J. F. Shaw (London: Encyclopedia Britannica Inc., 1952), Bk. 1, chapter 4.

${ }^{21}$ St. Augustine, City of God, Bk. 10, Chapter 22.

(c) 2015 Jove Jim S. Aguas

http://www.kritike.org/journal/issue 16/aguas june2015.pdf

ISSN 1908-7330

(c) BY-NC-ND 
St. Augustine therefore is telling us that while we naturally fall in love with the temporal order and material happiness, we need to realize that this is not our final destination. The ultimate end of our journey is union with God. What is needed therefore is to avoid the distractions of this world and focus on the end of our journey. We cannot be absorbed by the trappings of this world. Though we cannot deny the fact that like the wanderers we get distracted for indeed the world has its own grandeur, we need to realize that these are temporary and will not last forever. One way of resisting the temptations of the world is to practice the virtues of simplicity and humility. The heart that has so many desires of this world can be very restless and distracted. Pride which is the cause of the fall of Adam could lead to arrogance should be countered by humility. Humility restrains man from transgressing the will of God.

\section{Conclusion}

Lao Tzu and St. Augustine offer us complementary views as to how we should conduct ourselves in the modern world. For Lao Tzu human conduct should follow the way of the Tao, while for St. Augustine, it should conform to the command of God. While they take different points of views and starting points, both agree that there should be a guide to our conduct. For Lao Tzu, our guide is the way of the Tao and for St. Augustine, the law of God. Both advocate the importance of the virtues of humility and simplicity in one's conduct in society. They may differ as for the reasons for the value of these virtues. For Lao Tzu humility and simplicity are significant in human conduct in society because they safeguarded us from going to the extreme or reaching the opposite. For St. Augustine, these two virtues are important in man's journey towards God because they safeguard man from loving the physical and the material. Humility and simplicity are the opposite of arrogance and pride, vices which could lead man either to the extremes or to damnation.

St. Augustine and Lao Tzu both emphasized the importance of the spiritual. They may have different view of spirituality because for Lao Tzu it is taken from the concept of the Tao while for St. Augustine from his idea of God but they both recognized the value of the spiritual over the temporal. We should not be distracted by the temporal and contingent, instead we must focus on the things that are invariable and eternal. The world is indeed attractive especially because of its modern transformation, but they are contingent and temporary. The modern man is faced with various problems and he tries to solve these problems with material, economic, and sometimes military solutions. But the problems remain unsolved. St. Augustine and Lao Tzu are offering the modern man an alternative way, a

(c) 2015 Jove Jim S. Aguas

http://www.kritike.org/journal/issue 16/aguas june2015.pdf

ISSN 1908-7330

(c) $)$ BY-NC-ND 
way that is definitely old, but a wise alternative solution-moral-spiritual renewal and going back to nature. Greed and selfishness and other excesses of the modern man could be solved by the virtues of humility and simplicity, by man's turning and following the way of the Tao and the command of God.

Department of Philosophy, University of Santo Tomas, Philippines

\section{References}

Augustine, St., On Christian Doctrine, trans. by J. F. Shaw (London: Encyclopedia Britannica Inc., 1952).

The City of God, trans. by Gerald Walsh, Demetrius Zema, Grace Monahan \& Daniel Honan (New York: Image Books, 1958).

Augustine, St., The Confessions, trans. by John K. Ryan (New York: Image Books Doubleday, 1960).

Cleary, Thomas, The Essential Tao: An Initiation into the Heart of Taoism through the Authentic Tao Te Ching and the Inner Teachings of Chuang-Tzu (New York: Harper Collins, c1998).

Fung, Yu-Lan, A Short History of Chinese Philosophy, ed. by Derk Bodde (New York: Macmillan Publishing Co. Inc., 1966).

Kaltenmark, Max, Lao Tzu and Taoism (Stanford: Stanford University Press, 1969).

Kirkland, Russell, Taoism: The Enduring Tradition (New York: Routledge, 2004).

Liu, D., The Tao and Chinese Culture (London: Routledge and Kegan Paul, 1981).

Macmillan Encyclopedia of Philosophy, $2^{\text {nd }}$ edition, vol. 5 (New York: Thompson Gale, 2006).

Oates, Whitney ed., Basic Writings of St. Augustine (Michigan: Baker Book House,1948).

Portalie, Eugene, A Guide to the thoughts of St. Augustine (London: Burns and Oates, c1960).

Tao Te Ching, trans. by Ariane Rump (Hawaii: Society for Asian Comparative Philosophy, 1979).

(C) 2015 Jove Jim S. Aguas

http://www.kritike.org/journal/issue 16/aguas june2015.pdf

ISSN 1908-7330

(cc) BY-NC-ND 